\title{
Corrigendum: Regulation of output spike patterns by phasic inhibition in cerebellar granule cells
}

\author{
Thierry R. Nieus ${ }^{1}$, Lisa Mapelli ${ }^{2,3}$ and Egidio D'Angelo, ${ }^{2,3 *}$ \\ ${ }^{1}$ Department of Neuroscience Brain Technology, Istituto Italiano di Tecnologia, Genova, Italy, ${ }^{2}$ Neurophysiology Unit, \\ Department of Brain and Behavioral Sciences, University of Pavia, Pavia, Italy, ${ }^{3}$ Neurophysiology, Brain Connectivity Center, \\ C. Mondino National Neurological Institute, IRCCS, Pavia, Italy
}

Keywords: cerebellum, granule cell, GABA-A receptors, synaptic inhibition, modeling, spike timing

\section{A corrigendum on}

Regulation of output spike patterns by phasic inhibition in cerebellar granule cells by Nieus, T. R., Mapelli, L., and D'Angelo, E. (2014). Front. Cell. Neurosci. 8:246. doi: 10.3389/fncel.2014.00246

The corrigendum is needed in the acknowledgments section, since a funding agency was erroneously forgotten. We request therefore to add the sentence:

.... and by grants of the Italian Ministry of Health (RF-2009-1475845) to ED.

So that the full corrected paragraph will become:

\section{ACKNOWLEDGMENTS}

OPEN ACCESS

Edited and reviewed by: Graziella DiCristo, University of Montreal, Canada

*Correspondence: Egidio D'Angelo dangelo@unipv.it

Received: 28 January 2016 Accepted: 29 January 2016 Published: 16 February 2016

Citation:

Nieus TR, Mapelli L and D'Angelo E (2016) Corrigendum: Regulation of

output spike patterns by phasic inhibition in cerebellar granule cells.

Front. Cell. Neurosci. 10:30. doi: 10.3389/fncel.2016.00030
We thank Leda Roggeri for technical assistance. This work was supported by European Union grants [CEREBNET FP7-ITN238686, REALNET FP7-ICT270434, Human Brain Project (HBP604102)] and by grants of the Italian Ministry of Health (RF-2009-1475845) to ED.

We confirm that missing information does not affect the scientific validity of the results at any extent.

\section{AUTHOR CONTRIBUTIONS}

All authors listed, have made substantial, direct and intellectual contribution to the work, and approved it for publication.

Conflict of Interest Statement: The authors declare that the research was conducted in the absence of any commercial or financial relationships that could be construed as a potential conflict of interest.

Copyright (๑) 2016 Nieus, Mapelli and D'Angelo. This is an open-access article distributed under the terms of the Creative Commons Attribution License (CC BY). The use, distribution or reproduction in other forums is permitted, provided the original author(s) or licensor are credited and that the original publication in this journal is cited, in accordance with accepted academic practice. No use, distribution or reproduction is permitted which does not comply with these terms. 